\title{
Lexis
}

Journal in English Lexicology

$7 \mid 2012$

Euphemism as a Word-Formation Process

\section{The Expressive Creativity of Euphemism and Dysphemism}

\section{Miguel Casas Gómez}

\section{(2) OpenEdition \\ 1 Journals}

\section{Electronic version}

URL: http://journals.openedition.org/lexis/349

DOI: 10.4000/lexis.349

ISSN: 1951-6215

\section{Publisher}

Université Jean Moulin - Lyon 3

\section{Electronic reference}

Miguel Casas Gómez, «The Expressive Creativity of Euphemism and Dysphemism », Lexis [Online], 7 | 2012, Online since 25 June 2012, connection on 10 December 2020. URL : http:// journals.openedition.org/lexis/349; DOI : https://doi.org/10.4000/lexis.349

Lexis is licensed under a Creative Commons Attribution-NonCommercial-NoDerivatives 4.0 International License. 


\title{
The Expressive Creativity of Euphemism and Dysphemism*
}

Miguel Casas Gómez ${ }^{1}$

\begin{abstract}
Euphemism and dysphemism are two cognitive processes of conceptualisation, with countervalent effects (having the same base and resources but different aims and purposes), of a certain forbidden reality. The expressiveness immanent in these phenomena is so consubstantial that it explains not only its forbidden origin (the affective ambivalence of the taboo or the paradoxical description of its intrinsic essence), but also that sometimes the forbidden term does not exist, with the use of euphemistic/dysphemistic expressions that, given their connotative contents, go beyond what the corresponding forbidden terms would designate. It is precisely this expressive capacity of euphemistic and dysphemistic nature that shows that the dividing line between taboo and dysphemism is, on occasions, quite blurred, so that a taboo term is not readily available, and that the boundary between euphemism and dysphemism is not entirely clear. These conflicting emotions and antagonistic feelings facilitate the existence of dysphemistic euphemisms and euphemistic dysphemisms.

Likewise, there are several mechanisms with an expressive base, corresponding to different linguistic levels, which make use of these phenomena in order to modulate, substitute, alter or modify a certain forbidden concept or reality. In this paper, we will stick to linguistic description with examples from a set of specific resources, which are especially significative for their expressiveness, and which favour the appearance of linguistic creations, sometimes through a lexical substitute and at other times through a morphological modification of a forbidden content, such as expressive designations, verbal exchanges or composition, as well as those other cases in which the attenuating nature of the euphemism is intensified with expressive enhancement in the creation of certain substitutions for reasons of puffery, which are so common in expressions which give additional social prestige to certain professions, trades and jobs.
\end{abstract}

Key words: taboo - euphemism - dysphemism - expressive enhancement - politically correct language - expressive creativity

\footnotetext{
* This article has been included in the lines of research on "Communication linguistics" and "Lexical creation and formation" carried out in the framework of projects by the group belonging to the Andalusian Research Plan Semaínein [ref.: HUM 147], subsidised by the Andalusian Regional Government and belonging to the area of General Linguistics in the Department of Philology of the University of Cádiz. I would like to thank especially Mary Joplin for her translation of this paper.

1 University of Cádiz: miguel.casas@uca.es
} 


\section{The affective ambivalence of taboo}

The expressiveness of euphemism is a consubstantial part of its forbidden origin, an inevitable connection between feelings, emotions and antagonistic states which are the base of the Freudian theory [Freud 1967: 29-30, 46-47, 51 and 92-93] of the "affective ambivalence" of the taboo, consisting of an archaic prohibition which lives on in the unconscious, and the unconscious desire to transgress it. From this point of view, the double semantic value of the notion of "taboo", which also means "sacred fear", corresponds to an affective-emotional ambivalence at a psychic level, a struggle between fear and desire: the fear of the taboo person or object and the unconscious temptation of its infringement ${ }^{2}$. This ambivalent attitude or paradoxical situation that is adopted in the face of taboo prohibitions can be seen in the very characterization that certain linguists have made of the intrinsic essence of linguistic taboo: as Benveniste states [1977: 257], "la naturaleza de esta interdicción cae no sobre el "decir alguna cosa", que sería una opinión, sino sobre el "pronunciar un nombre", que es pura articulación vocal. Cierta palabra o nombre no debe pasar por la boca. Simplemente se retira del registro de la lengua, se borra del uso, no debe existir más. Sin embargo, y es condición paradójica del tabú, este nombre debe al mismo tiempo continuar existiendo como prohibido" [the nature of this interdiction refers not only to "saying something", which would be an opinion, but also to "pronouncing a name", which is pure vocal articulation. A certain word or name must not leave one's mouth. It is simply deleted from the register, removed from use, it must no longer exist. However, and this is a paradoxical aspect of taboo, this word must continue to exist as a forbidden element].

\section{From euphemism and dysphemism as lexical substitutes to euphemism and dysphemism as cognitive processes}

As constants that exist in almost all the descriptions of the euphemistic-dysphemistic phenomenon we can appreciate its limitation on a lexical level and a substitution process, as well as a patent confusion between substitute and process, which means the frequent identification of euphemism/dysphemism with euphemistic/dysphemistic substitute ${ }^{3}$, consisting of using the former to indicate the term that replaces the forbidden word (the lexical substitute) and not the lexical substitution itself or, more precisely, the linguistic manifestation.

In my recent papers [Casas Gómez 2009 and 2011] I have expressed my disagreement with the opinions expounded in my doctoral thesis and the publications deriving from it [Casas Gómez 1986, 1993, 1995, and 1996], in which I made the first of these mistakes, that of reducing euphemism/dysphemism to a lexical substitution,

\footnotetext{
2 As Freud states [1967: 47], "en su inconsciente, no desearían nada mejor que su violación, pero al mismo tiempo, sienten temor a ella. La temen precisamente porque la desean, y el temor es más fuerte que el deseo" [in their unconscious mind, they wish for nothing less than its violation, but, at the same time, they fear it. Their fear is stronger than their desire].

3 This is one of the most frequent confusions, criticised by several authors on the subject, that can be found in this field of study. For this and other terminological and conceptual clarifications in the area of interdiction, such as euphemism / dysphemism - euphemistic / dysphemistic substitute - euphemistic / dysphemistic use, taboo - euphemism, euphemism - dysphemism, euphemism / dysphemism - base linguistic mechanism, euphemism - synonymy, taboo - dysphemism, dysphemism - cacophemism - cacosemy, taboo interdiction and word taboo - conceptual interdiction, see my papers [Casas Gómez 1986: 36-40, 1995: 1746, 2000: 79-94 and, above all, 2005: 271-290].
} 
although I did in fact distinguish euphemism and dysphemism as processes for different euphemistic or dysphemistic substitutes or uses. Thus, after a first lexical formulation of the euphemism as a linguistic process used to neutralise a forbidden term by means of associative resources of a formal or semantic type, I later incorporated certain pragmatic components deriving from its essential relativity and its social, contextual and discursive characteristics, finally characterizing it as "un acto de habla, como la actualización discursiva por parte del hablante de unos sustitutos léxicos -habituales o lexicalizados $\mathrm{u}$ ocasionales o creativos- que, a través de un conjunto de recursos lingüísticos y paralingüísticos, permiten, en un contexto y situación pragmática determinada, neutralizar léxicamente el término interdicto" [a speech act, being the discursive use by the speaker of some lexical substitutes -habitual, lexicalised, occasional or creative- which, through a set of linguistic and paralinguistic resources, and in a certain pragmatically determined context or situation, allow the lexical neutralisation of a forbidden term] [Casas Gómez 1986 : 35-36].

Grateful as I am to Crespo Fernández [2007: 82] in one of the most recent monographic works on the subject, for considering this proposal as "la más acertada de las definiciones del eufemismo, al destacar su naturaleza, no ya social o lingüística, sino pragmatica o discursiva" [the most accurate definition of euphemism, since it highlights its pragmatic or discursive nature, rather than its social or linguistic aspect], I wish to carry out a genuine act of self-criticism and express my change of heart regarding the opinions expressed both in my doctoral thesis and in my first publications in the field of linguistic interdiction.

I am aware that, for the period in which it was made, this definition of euphemism contained various new aspects, above all of a pragmatic-discursive nature, but it also suffered from some limitations due both to the linguistic level which is the starting point of the analysis and, essentially, from the perspective adopted in the study. In my opinion, the positive features of this characterization centre on two aspects: 1 ) the definition of euphemism as belonging to speech, and not to the system, considering it to be a discursive use as a pragmatic aspect integrated in speech linguistics, since the communicative situation not only gives rise to but also truly justifies and is the "raison d'être" of euphemistic and dysphemistic uses and 2) the complete classification of linguistic mechanisms, not only those on a lexical plane, including phonetic, morphological, syntactic and other paralinguistic resources. However, the main negative aspect is that the proposed definition of euphemism still contained the limitation ${ }^{4}$ of implicitly characterizing the function of euphemism on a purely lexical level, as well as operating through substitution, as is evident, both in my considerations of the phenomenon, in which I refer specifically to substitution and the lexical or euphemistic substitute -as Crespo Fernández still does [2007], taking my position as a base for his own- or to lexical neutralisation of the forbidden term, as can be seen in the conclusions of this paper, in which I distinguish euphemism as a substitution process (and this is also applicable to dysphemism), from the different euphemistic and dysphemistic substitutes and uses. We can now add two further clarifications to these objections (the first, which is less relevant, is of a terminological-conceptual nature, whereas the second is fundamental to the new approach to the problem to which we refer here): 1) the necessity of using inverted commas round the verb "neutralise", since in the euphemism the principle of semantic neutralisation does not function as such ${ }^{5}$, but rather it appears as a designative fact that occurs in speech, that is, the so-called "neutralisation" becomes

\footnotetext{
${ }^{4}$ As Uría Varela so correctly observes [1997: 5-6].

5 As I have explained in later works [Casas Gómez 1993, 1995, 2000, 2005 and 2009].
} 
the "suspension" of all the connotative features dependent on the speaker, which leads to the conception of this phenomenon as a "factor de libertad y creación" [factor of liberty and creation] [Rodríguez Adrados 1967: 219]; 2) the starting point of this characterization is still the existence of a forbidden term and not a forbidden reality or one which is conceptually subject to interdiction.

The truth is that, in my first approaches to this area of study, I went no further than my predecessors who maintained, as in the majority of current formulations regarding this process, a narrow concept of euphemism or dysphemism, understood semantically as lexical substitutes or substitution processes in the Romanistic tradition ${ }^{6}$. In fact, just as semantics were first studied at the level of the word and later went on to be studied at other levels of analysis of linguistic content, in the field of euphemism/dysphemism, researchers concentrated exclusively on the lexical point of view although the problem is now approached from other perspectives, and, above all, from the analysis of other linguistic levels ${ }^{7}$.

However, in my more recent studies on interdiction [Casas Gómez 2000 and 2005], I have not only specified linguistically, from a conceptual point of view, a set of terms appropriate to this field (cf. n. 2), but also, above all, have made a distinction between word taboo, based on an internal psychological block suffered by the speaker, and concept taboo, or more exactly, conceptual interdiction in the broadest and most general sense of linguistic interdiction, whose causes are external and of an affective- associative nature, centring more on the hearer, along the same lines as the pragmatic 8

6 See the research carried out in different Romance languages by, amongst others, Galli de' Paratesi, [1973], Senabre [1971], Widłak [1968, 1970 and 1972], Montero Cartelle [1981], Kröll [1984] and Radtke [1980].

7 A Latin philologist, Uría Varela, was the first to adopt a new perspective, observing this circumstance in the revision of the definitions of euphemism made before his monographic work Taboo and Euphemism in Latin. To this end, he made the following clarifications: 1) euphemism cannot always be characterised as a lexical substitute; 2) its functioning should not be restricted exclusively to this linguistic level, and 3) above all, it is not necessary to identify the phenomenon at all times as a substitution process. In defence of this argument, he mentions the existence of "sustitutos eufemísticos que no son léxicos" [euphemistic substitutes which are not lexical] (gestures), "procesos eufemísticos que se plasman en el léxico, pero que no implican una sustitución, como los que se actualizan a través de fórmulas de excusa o de agrupaciones sintagmáticas" [euphemistic processes which have a lexical origin, but which do not imply a substitution, such as those which occur in excuses or syntagmatic groupings], and others which are neither lexical nor substitutive (intonation or tone of voice), concluding that, as well as the possible substitution, this process could include a modulation of the forbidden term, carried out verbally by means of excuses "que disculpen su emisión (anterior o inminente)" [that apologise for what is transmitted (before or after)] (such as if you'll forgive my saying so, if you'll pardon the expression, etc.) or through non-verbal devices of a paralinguistic type, such as intonation or tone of voice.

8 In recent years there has been a proliferation of definitions that highlight the pragmatic consideration of the phenomenon and that insist on its discursive characterization and the elements that take part in the euphemistic communicative process, above all regarding the interpretative role of the hearer due to the perlocutive effects that the corresponding euphemistic uses produce contextually in the receivers. As examples of this point of view, consider, for example, the theories of Allan and Burridge [1991: 11 and 2006: 31-33], Warren [1992: 135], Lechado García [2000: 14], Rodchenko (Algunos aspectos de la variabilidad de los eufemismos en el español contemporáneo [Some aspects of the variability of euphemisms in contemporary Spanish]) or Gómez Sánchez [2004: 45]. The relevance of this pragmatic and communicative perspective in the study of euphemism has been demonstrated by the fact that it has been dealt with in some of the more recent dictionaries of linguistics, such as the Diccionario de lingüistica moderna [Dictionary of Modern Linguistics] by Alcaraz Varó and Martínez Linares [1997: 219-220]. In this frame of analysis we can situate some of the more recent formulations on euphemism, such as those made by Armenta Moreno [2009b: 23], Edeso Natalías [2009: 147 and 150] and, especially, Crespo Fernández [2007: 82-83]. A critical revision of all these characterizations of euphemism can be found in Casas Gómez [2009: 732-733 and 2011: in press]. 
characterizations of the phenomenon which aim not to offend but to make the message more pleasant to the hearer. Precisely because of all these difficulties that appear in the descriptive study of interdiction from a linguistic point of view, I propose a broader concept of euphemism and dysphemism, not restricted to the lexical plane, which goes beyond a simple substitution process, which has led us to re-think and to characterise the euphemistic-dysphemistic phenomenon towards a cognitive dimension, founded, not on the base terms, but rather on conceptual categories or forbidden realities and on pragmatic suppositions more in accordance with the relative nature and the essentially discursive performance of such linguistic processes. Given these considerations, which imply a new theoretical treatment of the facts, let us compare my previously mentioned characterization with this very different definition in which we conceive euphemism or dysphemism as "the cognitive process of conceptualization of a forbidden reality, which, manifested in discourse through the use of linguistic mechanisms including lexical substitution, phonetic alteration, morphological modification, composition or inversion, syntagmatic grouping or combination, verbal or paralinguistic modulation or textual description, enables the speaker, in a certain "context" or in a specific pragmatic situation, to attenuate, or, on the contrary, to reinforce a certain forbidden concept or reality" [Casas Gómez 2009: 738].

\section{The expressiveness of euphemism and dysphemism}

Euphemism and dysphemism are two cognitive processes of conceptualization with contravalent effects (having the same base and resources but different aims and objectives) of a certain forbidden reality.

The expressiveness immanent in these phenomena is so consubstantial that it explains not only their forbidden origin: the aforementioned affective ambivalence of taboo or the paradoxical characterization of its intrinsic essence (cf. 1), but also the lack of a base term in the case of euphemistic-dysphemistic uses which, given their connotative content, go beyond the meaning of their corresponding forbidden terms. In relation to the limitation of reducing euphemism or dysphemism to the lexical plane and its substitution processes outlined in the previous section, Uría Varela [1997: 6] has already pointed out that in this area we run up against an additional problem: "Existen realidades interdictas que parecen carecer de término de base, esto es, que sólo tienen expresión eufemística [yo añadiría "o disfemística"] y en las que, por tanto, es impropio hablar, al menos en sincronía, de sustitución" [there are forbidden realities that appear to lack a base term, that is, which have only a euphemistic expression [I would add "or dysphemistic"], in which case, at least synchronically, it is inappropriate to speak of substitution], a difficulty which underlines the fact that in the area of interdiction, lexical substitution is not everything. Conveniently, this gives us the opportunity to approach the process not from a forbidden term, but rather from a forbidden "content" or reality9.

\footnotetext{
9 With these comments, he agrees with me that euphemism must be considered, not as a systemic phenomenon, but as a discursive one, in the frame of a pragmatic definition integrated in speech linguistics, characterizing it as "el conjunto de mecanismos lingüísticos que, basándose en una alteración, modulación o sustitución de formas o contenidos lingüísticos interdictos, proporcionan al hablante la posibilidad de comunicación atenuada de un sector de la experiencia" [a set of linguistic mechanisms, which, coming from alteration, modulation or substitution of forbidden linguistic forms or contents, provide the speaker with the possibility of the attenuated communication of one field of experience] [Uría Varela 1997: 6].
} 
It is indeed the expressive creativity of the euphemistic and dysphemistic uses that shows, in the first place, that we do not always dispose of a taboo term, and furthermore, that the dividing line between taboo and dysphemism is sometimes quite blurred and, likewise, the boundary between euphemism and dysphemism is not always clear. These conflicting emotions and antagonistic feelings give rise to the existence of dysphemistic euphemisms and euphemistic dysphemisms, as we shall see in the next section.

In fact, within this general field of interdiction it is not always clear exactly which is the taboo term and which is the dysphemistic one (as in the case of devil-demon or fuck - shag), leading to the frequent identification of taboo with dysphemism. This failure to distinguish between the two concepts derives, fundamentally, from the difficulty implied in trying to start, not so much from a forbidden reality, but rather from a base term ${ }^{10}$. This means the boundary between both phenomena is not well-defined, and neither is it clear which element functions in synchrony as the taboo (sometimes this can only be discovered from a diachronic viewpoint, since it has disappeared from the speakers' consciousness) and which is dysphemistic. No doubt, it is the expressive capacity, which participates as a fundamental function of the interdictive process, that justifies the fact that, occasionally, we do not have the forbidden term at our disposal, since the respective euphemistic and dysphemistic uses express contents about which the base term gives no information. In fact, sometimes it seems that the forbidden term does not even exist, although, of course, there is a forbidden concept or reality, which leads us to wonder if, instead of a forbidden vocabulary (as a base for substitution), we should be talking of a conceptual interdiction as the starting point for different euphemistic or dysphemistic formulations.

\section{Dysphemistic euphemism vs. euphemistic dysphemism}

Both euphemistic and dysphemistic affective tendencies combine to the point where, sometimes, euphemistic forms occur with a pejorative value, and above all, dysphemistic forms may have a euphemistic function, in all cases depending, once more, on the emphasis or communicative intention on the part of the speaker when producing the verbal or non-verbal (such as in the case of gestures) expression. Of the two forms, the latter, dysphemistic use with a positive effect, is without doubt the most widely used due to the fact that "las emociones desagradables no sólo son más abundantes que las agradables, sino que también su tono emotivo es de mucha mayor intensidad" [unpleasant

\footnotetext{
10 Consider, for example, the base term related to the "other world" or the "afterlife" or, especially, to the forbidden conceptual area around "lavatory" [Casas Gómez 1995: 28-32), which shows a type of instability of the euphemism consisting of a constant change of substitutes which exist both simultaneously and successively alongside the taboo term, but they never actually take its place; all that may happen is the decadence of the term itself, which may be relegated to a diastratic level, or to a certain specific lexicon. The fact that the taboo term outlives its substitutes contrasts with the constant euphemistic regeneration, which, in some cases, is so brief, that it could be said, not that the euphemism is "born to die", but that it is "born dying". This is what happens with the lexical instability of the numerous substitutes generated by the forbidden reality of the "lavatory", in which certain ambiguous substitutes such as restroom, bathroom, toilet, powder room, among others, may refer, metonymically, to the place or the action, as can be seen in contexts like "I'm going to have a sh... I mean to the bathroom" (an expression normally accompanied by a paralinguistic verbal modulation).
} 
emotions are not only more common than pleasant ones, but their emotive tone is much stronger] ${ }^{11}$.

The former aspect has been studied by Silva Correia [1927: 778-779], who suggests some fields in which the "fórma lisongeira pode ter alcance agressivo" [the flattering manner can produce an aggressive effect], such as in the case of words expressed with a favourable semantic value, which, however, are interpreted as irritating by the hearer, although the disposition may be quite friendly. Also, between people who are normally on first-name terms the use of a more polite form of address may cause some annoyance and even be considered insulting. An interesting example of these forms of address can be found in the following text "Yes, yes, sir" by Luis Eduardo Aute [Album 1966-67, my italics]: "Sí, sí, señor / y ¿qué le vamos a hacer? / yo le he perdido el respeto / y por eso le trato de usted. / ¿Por qué se empeña, señor, / que le rinda admiración? / no me pondré a sus pezuñas / pues tienen muy mal olor. / No quiero ser un señor / de buena reputación; sólo pretendo ser hombre, / cosa que usted no logró. / Quédese usted con su dios / puesto que usted lo inventó; / me gustan más mis pecados, / ésos que usted condenó. / Le dedico esta canción / con todo mi corazón. / Espero haberle irritado, / pues ésa fue mi intención". [Yes, yes, sir, and what can we do about it? I've lost my respect for you/ that's why I call you "usted". Why do you insist, sir, that I express my admiration for you? I won't fall at your hooves because they smell terrible. You can keep your god, since you invented him; I prefer my sins, the ones that you condemned. I dedicate this song to you with all my heart. I hope I have annoyed you, as that was my intention].

Likewise, Grimes [1978: 17 and esp. 22] talks of pejorative or condemning euphemisms with reference to those which represent "proper" speech only from the point of view of the forbidden terms that they replace, at the same time as they condemn it through a negative value judgment, as occurs, for example, in do the evil act for fuck, and ruin, dishonour or deflower in the sense of "to take a woman's virginity".

However, the opposite cases, in which rough terms become friendly words, are undoubtedly more common, not only when they are used in the diminutive form, which propitiates an affectionate disposition, but also when they are used with familiarity as terms of endearment ${ }^{12}$, reversing the meaning. This is something which occurs only in

11 Grimes [1978: 24], who, on the same page goes on to say: "Así cuando el hablante quiere expresar el cariño en grado intenso, ignora la cualidad de la emoción y selecciona un signo lingüístico más adecuado a su intensidad, o sea una expresión que normalmente expresa la afectividad negative" [Thus, when the speaker wishes to express strong affection, he ignores the emotional quality and chooses the most suitable linguistic sign to reflect its intensity, that is an expression normally used for negative affectivity]. Similarly, Kany [1969: 75] states that "los referentes desagradables son más numerosos que los agradables y su tono emotivo es mucho más intenso. De ahí que en momentos de intensa emoción la consciencia del hablante se vea invadida de palabras injuriosas" [unpleasant references are more frequent than pleasant ones and their emotive tone is much stronger. For this reason, at times of intense emotion the speaker's conscience is filled with offensive words].

12 As Vendryes states [1967: 240], "las más violentas palabras que puedan emplear la cólera o el odio admiten un uso suavizado, enternecido; se emplean como expresión amistosa, que excluye todo menosprecio, todo vituperio" [the most violent words that can be used in anger or hatred may have a gentler, tender use, which leaves aside all disdain and vituperation]. See also Daniel [1980: 16]: "el tono o la intencionalidad del hablante pueden modificar por completo el valor de una palabra. Las expresiones más injuriosas adquieren no pocas veces carácter afectuoso. Por ejemplo, cuando dos amigos se saludan con un $<<$ iHola, cabronazo! ¿Qué te cuentas? $>>$ Muchos términos que se consideran vulgares por su significado se hallan tan incorporados al lenguaje corriente, a veces como simples muletillas conversacionales o como exclamaciones (ijoder!, ¡coño!, ¡leche!), que han perdido toda contaminación sexual" [the tone and the intention of the speaker can completely alter the value of a word. The most offensive expressions often acquire an affectionate tone. For example, when two friends greet each other 
very close personal relationships, in which, as well as these factors of an affective nature, the intonation and gestures of the speaker are of vital importance.

This type of construction has been analysed by Kany [1969: 75] in the group of metaphors based on a similar perceptive or emotive effect ${ }^{13}$ :

A una palabra injuriosa empleada como término cariñoso se la llama cacofemismo, antítesis del eufemismo. La transferencia es de naturaleza puramente emotiva (...). El oyente pasa por alto el valor intelectual del vocablo. Percibe la intensidad del tono emotivo antes que su calidad particular o su dirección, y se guía además por la entonación y el gesto del interlocutor.

[An offensive word used affectionately is called cacophemism, the antithesis of euphemism. The transfer is purely emotional (...). The hearer overlooks the intellectual value of the word and he perceives the intensity of the emotional tone before its specific quality or direction, and is also guided by the speaker's intonation and gesture].

Kany's use of the term cacophemism -generally an alternative to dysphemism- as the antonym of euphemism is surprising, to refer to an "palabra injuriosa empleada como término cariñoso" [offensive word used affectionately], which would mean a restriction on the meaning, since cacophemism is an offensive expression irrespective of its use, affectionate or otherwise [Contreras 1966-68: 176]. As we already showed in a previous work [Casas Gómez 2005: 279-280], in which we discussed and established the relationships between the denominations used in this field: dysphemism, countereuphemism, anti-euphemism, cacophemism and cacosemy ${ }^{14}$, it is preferable to restrict the use of the concept of dysphemism to indicate any manifestation with an underlying interdictive repression and not to use it in the broad sense of substitution of a forbidden or even positive or neutral term, for another, more vulgar one. In these cases, it is better

with "Hello, you old bastard! How are things?" Many expressions, such as ijoder! [fuck] and ;coño! [cunt] ¡leche! [spunk] T.N. that are considered vulgar because of their meaning, have become so incorporated in everyday language, often as tags or exclamations, that they have lost all their sexual contamination].

T.N. The word coño in Spanish is in everyday use and is relatively inoffensive, unlike its English equivalent. Leche (lit. milk) is used as an expression of surprise and is also considered inoffensive.

13 With regard to these affective metaphors, see Ullmann [1976: 241], who distinguishes two types of similarity: objective and emotive.

14 The most widely-used expression is, no doubt, dysphemism, a term used by Carnoy [1927: 351-356; cf. also Bueno 1960: 240-246; Grimes 1978: 16-19; Cela 1975: 27; Mansur Guérios 1956: 24-25; Montero Cartelle 1981: 86; Montero Cartelle 1973: 22; Casas Gómez 1986: 81-96; Chamizo 2004: 45-51, 2005: 9-16, 2008: 31-46 y 2009: 428-446; Chamizo y Sánchez Benedito 1994: 78-92 y 2000: 23-65; Edeso Natalías 2009: 148-151; Crespo Fernández 2007: esp. 153-210 y 2008: 95-110, or Armenta Moreno 2009a: 236-272 y 539 625, 2009b: 17-24 y 2010: 120-124], to designate with maximum accuracy the inverse phenomenon of euphemism, which does not mitigate, dissipate or attenuate the connotations of the forbidden word, but, on the contrary, motivates and further reinforces its associations. However, some authors have used different denominations, sometimes with certain restrictions on the meaning. Thus, Silva Correia [1927: 757-778], whilst describing this process in general as dysphemism, frequently uses other synonyms such as countereuphemism, anti-euphemism and, above all, cacophemism. In the case of Grimes [1978: 16], although he distinguishes both dysphemism and insult within the process of the linguistic evocation of the forbidden term, he widens the concept of dysphemism to include under this heading, not only "aquellos términos que representan la expresión popular recta, aunque dura y malsonante, de los conceptos tabús" [those terms that represent straightforward popular expression, although they may be crude and offensive, of taboo concepts], but also "aquellas expresiones de connotación negativa que, sin ser fórmulas injuriosas estereotipadas, sustituyen a términos positivos o neutrals" [those expressions with negative connotations that, not being typical insults, replace positive or neutral ones]. Closely related to the field of dysphemism from a lexicographical point of view is the work on the insult by Luque, Pamies and Manjón [1979]. 
to use the term cacosemy, suggested by Rabanales [1958: 279], to refer to those "denominaciones del habla familiar claramente peyorativas, que se emplean cuando se quiere menospreciar el valor de un objeto o de una persona" [clearly pejorative familiar expressions which are used in order to disdain a person or an object].

Dysphemism is associated with insult in this kind of affective combinations, since such emotive dysphemistic uses constitute insults made in a positive tone which contrast with normal conceptual dysphemistic uses, the former being more usual in familiar relationships ${ }^{15}$, especially between parents and children, friends, partners and in certain social circles.

A singular example of the use of these formulae used to express praise, a phenomenon which also exists in other languages [Kröll 1981: 109], can be observed in the word puta [whore, bitch] and its offensive expressions, which are among the most common swear-words or insults in our daily lives. The expression puta [bitch] or hijo de puta [son of a bitch] appears in two different contexts: a) functioning in its own area of signification, in which it acquires positive or negative semantic content, and b) functioning in a different lexical field, losing almost all its conceptual value and in a derogatory sense. The energetic crudeness of the taunt has led to an infinite number of expressions which work as euphemistic or dysphemistic substitutes, called pseudoeuphemisms by Martín [1979: 140-141], based on semantic or phonetic relationships: hijo de cual, hijo de cualquiera, hijo de la Gran Bretaña, hijo de la gran China, hijo de la grandísima, hijo de la grandísima cabra, hijo de la gran cerda, hijo de (la gran) perra, hijo de la grandísima puerca, hijo de madre o de su madre, hijo de mala madre, hijo de pucha, hijo de tal, hijo de una, hijo de zorra, etc.T.N. [Cela 1976-77, III: 716, Martín 1979: 141 y León 1980: 81]. There are several comparative expressions such as "más puta que las gallinas" [a bigger whore than Mata Hari], which has given rise to substitutions like "casi tan zorra como las gallinas" [a bigger slut than Mata Hari]. As we can see here, with the mediation of paralinguistic and extra-linguistic factors, these expressions can acquire affective value. However, the expression puta sometimes loses its original meaning and functions, depending on the use, in different areas of signification: "esta enfermedad es muy puta" [this illness is a bitch] (used about something bad or harmful); puta calle [fucking street] or puta vida [fucking life] (used with scarcely any conceptual value and in a pejorative sense); ;la (muy) puta! [bloody hell!] (an exclamation of surprise, amazement or anger), pasarlas putas [to have a fucking hard time], de una puta vez [once and for all], como una puta cabra [mad as a fucking hatter], ni puta idea [no fucking idea], etc. (expressions with varied meanings). It is surprising that, in all these cases, although the word puta is used outside its semantic field and is practically devoid of any significative charge, society still relates it to its original association, thus giving rise to substitutions like perra vida [a

\footnotetext{
15 Father Restrepo [1917: 40] mentioned the influence of feelings on semantic change: "Los mimos de las madres llegan hasta aplicar a sus hijos nombres afrentosos, que tocados por el cariño maternal se convierten como por encanto en lo más dulce y expresivo de la lengua. Así cambian ocasionalmente de sentido voces como pícaro, granuja, gandul, bribón, pillo, tunante, negro, chato. El mismo monín, que hoy tanto se oye, no es sino el diminutivo de mono". [A mother's affection leads her to call her children offensive names, which, touched by maternal affection, are magically turned into the sweetest and most expressive parts of the language. In this way, words like rogue, rascal, scallywag, scamp, naughty, villain, black and snub-nose change their senses. Even little monkey, which is heard so often today, is simply the diminutive of monkey]. Kany [1969: $76 \mathrm{ff}$ ] expressed a similar opinion: "El proceso puede ilustrarse con los numerosos ejemplos de cacofemismos empleados con los niños. La madre, al dirigirse a su hijo, a menudo emplea un término injurioso que satisface el elevado grado de su amor y ternura". [The process can be illustrated with the many examples of cacophemisms used for children. The mother, addressing her children, often uses an insulting term with the maximum level of love and tenderness].

T.N. A variety of expressions used as alternatives to hijo de puta comparable to son of a gun for son of a bitch.
} 
dog's life], cochina vida [a sow's life], puerca vida [a pig's life], pasarlas furcias [to have a hard time], ni zorra idea [no bloody idea], ni ramerísima idea [not the foggiest idea], ni meretriz idea [no damned idea], etc. Likewise, in a friendly conversation we can hear expressions of the type “iQué hijo puta eres!” [What a son of bitch you are!] or “¡El hijo de puta ha sacado las oposiciones!" [The son of a bitch has passed all his exams!], with the intention only to praise, just as adolescent girls, among themselves, may call one other affectionately puta [bitch] or, between couples, he may say to her: "Qué puta eres!" [What a bitch you are!] used with no wish to insult, but rather with intense affection and fondness. There is also a large selection of euphemistic dysphemistic uses in the language of prostitution, which is especially characterised by the use of a great many violent terms in an affectionate way. It is not only prostitutes who make continuous use of these constructions, but rather, the diverse relationships (madame - prostitute, client - prostitute, pimp - prostitute, or prostitute - prostitute) existing around their social environment have led to the propagation of these forms. Thus, just as terms like niña, chica, muchacha, compañera, nena, muñeca, paloma, pequeña, maja, etc. [little girl, child, teenager, partner, baby, doll, chick, etc.], sometimes used in the diminutive form ${ }^{16}$, can become contaminated when used in an erotic sense, losing their original value and, in some cases, functioning as euphemistic or affective substitutes for "prostitute", so, dysphemistic expressions such as puta, zorra, cerda, guarra, puerca, etc., can take on clearly favourable connotations in these social circumstances.

\section{The expressive enhancement of euphemism}

Many authors have highlighted both the covering and, especially, the attenuating function of euphemism. For this reason, although encyclopaedias and dictionaries of linguistics are full of extra-linguistic characterisations of this phenomenon ${ }^{17}$, there are a few exceptional linguistic formulations suggested by authors such as Lewandowski [1982: 128]: "Encubrimiento del significado. Forma de la circunlocución cortés; denominación velada de tipo atenuante o encubridor, p. ej., él se ha puesto fuerte, en vez de se ha puesto gordo; un señor mayor, vivir en condiciones modestas, tener una relación, etc.". [The covering of meaning. Means of polite circumlocution; veiled denomination with the intention of attenuating or covering, e.g. He's filled out, instead of he's got fat, an elderly man, to live in straitened circumstances, to have a relationship with, etc.] or Cerdà [1986, s.v. eufemismo): "Palabra o expresión que sustituye a otra con objeto de encubrir, disimular o atenuar su significación considerada molesta o inoportuna; p. ej., invidente en lugar de ciego, tercera edad por vejez". [Word or expression that substitutes another with the object of covering, dissembling or attenuating a meaning considered unfortunate or inappropriate; e.g. visually impaired instead of blind, senior citizen instead of old age], which, although they are limited, as generally occurs and as we have mentioned before, to a substitution process on a lexical plane, underline the attenuating and covering effect of euphemism, used as a disguise which can mask reality. Likewise, in one of the most recent monographic works on euphemism, Horak [2010: 12], after describing some of

\footnotetext{
16 These words can be interpreted as terms of endearment in this social environment, as they can in other circumstances. This semantic-expressive resource, which Rabanales [1958: 287-292] called calosemy, is usually accompanied by a special inflection in the voice and an exclamatory tone which further accentuates the intensity of the affection.

17 As I have tried to show, with numerous materials, in recent papers on the different linguistic and nonlinguistic visions of the process [Casas Gómez 2009: 727-733 and 2011: in press].
} 
the fundamental problems in the definition of this phenomenon, bases his position on that of López Eire [1999: 315], for whom "en un principio y básicamente, el eufemismo es el concepto de un proceso (...)" [in principle and basically, euphemism is the concept of a process (...)], going on to characterise it, not as the attenuated expression of a notion, but as a process of attenuation, "un procédé figuré qui améliore la négativité d'une réalité (subjectivement) taboue" [a figured process that improves the negative aspect of a (subjectively) taboo reality] [Horak 2010: 62]. Nonetheless, it must not be forgotten that, together with these two pragmatic-discursive functions, and sometimes combined with both of them, the function that stands out above all is that of emphasizing or enhancing expressively a certain reality, considered socially unacceptable, with the aim of giving it prestige, as is the case of the euphemistic uses which are traditionally classified as "puffery", and which are so common in expressions implying a higher social echelon for certain professions, trades and jobs, such as prison warden for jailer, sales and marketing assistant for salesperson, urban property employee for janitor, flight attendant for air hostess, rodent operative for rat catcher, interior/exterior designer for window dresser, shoe repairer for cobbler ${ }^{18}$ and so on, and in which case the softening or attenuating effect characteristic of the euphemistic process combines with, or rather, is intensified by, the expressive emphasis of these corresponding creative formulae. Indeed, with regard to some of the examples mentioned, Edeso Natalías [2009: 158159], in order to show that positive politeness serves not only to attenuate but also to emphasise or enhance [Hernández Flores 2004: 95-98], makes the following comment:

Nos gusta más empleado de finca urbana que portero porque con el primer término se acentúa el hecho de que se trata de un trabajo realizado en un entorno urbano; auxiliar de vuelo insiste en la idea de que es una profesión que se desempeña en las alturas (posiblemente para evitar la confusión con las azafatas de eventos); funcionario de prisiones pone el acento en el término funcionario, trabajo deseado por la mayoría de la población y asociado a la idea de que, para conseguirlo, es necesario aprobar una dura oposición; diseñador de interiores/exteriores sugiere la idea de un oficio artístico, asignando a quien lo desempeña capacidad creativa, ingenio, etc., valores todos ellos socialmente apreciables. En suma, con estos eufemismos se atenúan los rasgos asociados a las profesiones que designan (probablemente el rasgo esencial que las caracteriza es que no se necesita una carrera universitaria para desempeñarlas), a la par que se acentúan los positivos, de manera que con el término eufemístico estos empleos se transforman en profesiones de prestigio.

[We prefer urban property employee to janitor because with the first term we emphasise the fact that the work goes on in an urban environment; flight attendant because it is a profession whose work is carried out in the air (possibly to avoid confusion with event hostesses), prison public servant (prison warden) to jailer because it emphasises the term public servant, which is a much desired profession and is associated with the idea that workers are required to pass difficult public exams; interior/exterior designer suggests the idea of an artistic profession, requiring creativity and ingenuity, which are admired social skills. To sum up, with these euphemisms, we attenuate the features associated with the designated professions (perhaps the basic feature of all of them is the fact that a university degree is not necessary) at the same time accentuating the positive aspects, so that with the euphemistic terms these jobs become prestigious professions].

18 A form seen in on a sign in a shoe-shop, which, besides, was clearly motivated humoristically by the identification of the word zapatero [cobbler, shoemaker] with the surname of the current Spanish Prime Minister. 
In one of the classic works on euphemism and within the framework of the substantial differences in this phenomenon according to a number of characteristics (period, place, country, social class, sex, age and circumstances), Silva Correia [1927: 747-752] connected the rather undemocratic tendency of euphemistic language ${ }^{19}$, that is, the euphemistic features depending on social class, with the professions whose names are normally avoided, being replaced by diverse euphemistic formulae. With the creation of what he calls "eufemismos de megalomanía" [puffery euphemisms], which were very fashionable even at the beginning of the last century, there is a tendency, in this way, to ennoble the names of certain trades and arts. In fact, expressive enhancement has existed for some time, as can be seen in the following text by Antonio Gala, which reflects this trend in his article "Los bajitos" [Short people], included in his collection Charlas con Troylo (Madrid, Espasa Calpe, 1981: 143-144, my italics):

Es tremendo vivir en una época de culto a la apariencia (...). El asunto comenzó por los títulos. Los peritos fueron ingenieros técnicos; las criadas, empleadas de hogar; las enfermeras, auxiliares de clínica o de quirófano; los practicantes, asistentes técnicos sanitarios; losporteros, empleados de fincas urbanas. Está bien: que cada cual se llame como quiera: todos hemos ascendido en denominaciones. Pero -no es infrecuente- los nombres consiguen afectar a la esencia de las cosas. Ya nadie se siente a gusto en el sitio que, en realidad, le corresponde, con lo cual derrochamos una bilis generalizada que tiembla el misterio. Porque hemos perdido el orgullo y la seguridad, amplios y hermosos, de la base, y andamos montados en el aire como malos diamantes sin pulir. Los carpinteros se consideran tallistas; los sacadores de puntos, escultores; las putas, artistas (no en lo suyo, sino en sentido estricto), y así las demás honestas profesiones.

[Living in times of the cult of appearances is tremendous (...). The whole thing started with job titles. Experts became technical engineers; maids became domestic employees; nurses, hospital auxiliaries or surgical auxiliaries; registered nurses, technical sanitary assistants;janitors, urbanproperty employees. This is all very well, everybody is free to call themselves as they please: we have all been promoted in name. But -and this is not unusual- these names begin to affect the essence. Now nobody is happy to be in what is really their rightful place, and we brim over with generalised bile which reveals the truth: we have lost the full and beautiful pride and self-confidence of the base, and we are mounted in the air, like false, unpolished diamonds. Carpenters believe themselves woodcarvers; pencil sharpeners, sculptors; whores, artists (not in their work, but in the strict sense of the word), and so on with other honest professions].

In this way, to refer to the "oldest profession", as well as the example mentioned above (artist), in my doctoral thesis [Casas Gómez 1986: 233-234] we saw that the word whore, so offensive and insulting, especially for those who work as such, is softened with a whole range of hyperbolic designations founded on a metaphorical creation with its base in the profession or in the erotic interpretation of another profession which is socially considered, such as academician, sexual assessor, sexual assistant, social assistant, love (or sex)professor, love goddess, erotic employee, sex worker, French teacher, bar psychologist, love worker or sexologist.

\footnotetext{
19 A popular Spanish verse illustrates this very clearly: "Cuando se emborracha un pobre / Le dicen el borrachón; / Cuando se emborracha un rico: ¡Qué gracioso está el señor!”. [When a poor man gets drunk, they call him a drunkard;/ when a rich man gets drunk:/ what an amusing gentleman!] [Cuentos y poesías populares andaluces, 1916: 343, cit. by Nyrop 1913: 314 and Silva Correia 1927: 732].
} 
For these reasons, in relation with the strategy of politeness of euphemistic uses, and as an element that gives a positive image of both speaker and hearer ${ }^{20}$, Edeso Natalías [2009: 148, 156-159 and 161-162] discerns two types of euphemism, including, along with those that constitute a mechanism for the attenuation of a conceptual reality, those which imply "un doble mecanismo de atenuación y de realce, ya que suavizan los rasgos más negativos asociados a su referente y, a la vez, enfatizan los más positivos" [a double mechanism of attenuation and enhancement, since they soften the more negative aspects of their reference point, at the same time emphasizing the positive ones] [op. cit.: 161], pointing out that there are few of the latter type, referring to the field of work and the professions, in comparison with the first group. However, it is true that in recent years expressive enhancement of this type euphemistic tendency has increased in intensity, especially in the realm of politically correct language ${ }^{21}$, as Reutner [2010: in press] correctly puts it in a brief survey of euphemism as a historical-cultural phenomenon:

En este sentido podemos también clasificar, dentro de lo políticamente correcto, el cambio de perspectiva que proporcionan las nuevas denominaciones de profesiones que necesitaban una revalorización: azafata se convierte en tripulante de cabina o auxiliar de vuelo, portero en el supuestamente más elegante, afrancesado conserje. Abundan entretanto también los asistentes (asistenta 'chacha') y funcionarios (funcionarios de prisiones 'carcelero'), y prosperan además creaciones con agente (agente sanitario 'barrendero'), profesor (profesora en parto 'comadrona') y técnico: para el aparcacoches técnico en aparcamientos o para el vendedor técnico comercial.

[In this sense, in the area of political correctness, we can also classify the change of perspective that brings about the new names for professions that needed to be reevaluated: air hostess becomes cabin crew or flight assistant, janitor becomes the supposedly more elegant French word, concierge. There are also many assistants (assistant "char") and officers (prison officer "jailer"), as well as creations with agent (sanitary agent "road sweeper"), instructor (birth instructress "midwife") and technician: for car parker, car park technician or for salesperson, commercial technician].

\footnotetext{
20 "El eufemismo favorece la imagen positiva en la medida en que constituye un mecanismo de cortesía, también positiva, ya que supone el deseo de ser aprobado por los demás o, al menos, de no ser recriminado por nuestras palabras (...). En suma, el eufemismo atenúa los rasgos negativos de su referente, a la vez que como elemento de cortesía positiva refuerza la imagen positiva tanto del locutor como del interlocutor". [Euphemism favours a positive image insofar as it is a mechanism of politeness, which is also positive, as it expresses the desire to please others, or at least, not to be criticised for what we say (...]. To sum up, euphemism attenuates the negative aspects of its point of reference, at the same time being an element of positive politeness which reinforces the positive image of both speaker and hearer] [Edeso Natalías 2009: 156 y 157-158]. In a previous work, Crespo Fernández [2005: 77-86] analysed euphemistic strategies in relation to the concept of "face", within the framework of verbal politeness, in an attempt to show that euphemism, politeness and face are interrelated phenomena. Thus, in correlation with the two sides of politeness, the notion of "face" performs a two-fold function, acting as a preserver of the public self-image and autonomy of the participants in communication: "positive face (identified with the individual's desire to be positively regarded in social context) and negative face (concerned with the participant's desire to be autonomous and free from imposition). Euphemism acts on each of these two dimensions of face: first, it responds to the speaker's need to soften potential social conflicts which may alter the interlocutor's prestige; second, it supposes a way to minimize a threat to the interlocutor's autonomy" [op.cit.: 83].

21 See also on this subject the current works by Guitart Escudero [2003 and 2005: esp. 31-59] and Armenta Moreno [2009a: 29-56, 2009b: 9-12 and 2010: 115-129].
} 
Thus, this intensifying resource has increased its linguistic creativity by means of coining a range of expressive forms that give distinction to the person and prestige to all kinds of professions, trades and jobs, such as those mentioned here and those analysed in various recent studies on the subject, and even through the most absurd, exaggerated and deliberately comical expressive forms that appear on the internet and which, consequently, have been humorously ridiculed there: internal movement and information coordinator (porter), logistics and document distribution specialist (messenger), visual therapy expert (stripper), door admissions supervisor (bouncer), nocturnal activities supervisor (night watchman), external human resource distributor (taxi driver), petroleum transfer engineer (petrol pump attendant), mortar logistics engineer (bricklayer), advanced logistics engineer (motorcycle messenger), general and unspecified issue consultant (fortune teller, clairvoyant), information distribution officer (leafleter), field nourishment consultant (waiter), perishable goods distribution officer (greengrocer), field distributor of imported goods (street seller), expert in sexology and personal relations therapist (prostitute), highway environmental hygienist (road sweeper), expert in freelance activity (will do anything), landscape and plant engineer (gardener), music and film distribution expert (hawker of pirate CDs), unimportant affairs assistant (Member of Parliament).

As is clear in these examples, the widespread current use of this intensification mechanism with discursive value, in combination with other pragmatic functions, has led me to modify partially, or rather, to widen ${ }^{22}$ the linguistic characterization of these two phenomena formulated in my article "Towards a new approach to the linguistic definition of euphemism" [Casas Gómez 2009; cf. 2], now incorporating, as well as aspects such as covering and expressive enhancement, the important part played by the hearer in euphemistic or dysphemistic communicative interaction, with the result that we finally describe euphemism or dysphemism as

el proceso cognitivo de conceptualización de una realidad interdicta, que, manifestado discursivamente a través de la actualización de un conjunto de mecanismos lingüísticos de sustitución léxica, alteración fonética, modificación, composición o inversión morfológica, agrupación o combinatoria sintagmática, modulación verbal 0 paralingüística o descripción textual, permite al hablante, desde un punto de vista comunicativo en el que tiene presente la posible interpretación del oyente por los efectos perlocutivos que los usos eufemísticos/disfemísticos pueden provocar en los interlocutores, la creación intencional de todo tipo de expresiones verbales y no verbales o actos de habla, que, en un cierto "contexto" y en una concreta situación pragmática, encubren, atenúan o realzan expresivamente, o, por el contrario, motivan o refuerzan evocativamente un determinado concepto o realidad interdicta

[the cognitive process of conceptualization of a forbidden reality, which, manifested in discourse through the use of a set of linguistic mechanisms of lexical substitution, phonetic alteration, morphological modification, composition or inversion, syntagmatic grouping or combination, verbal or paralinguistic modulation or textual description, enables the speaker, from a communicative standpoint in which he takes into account the possible interpretation of the hearer due to the perlocutive

\footnotetext{
22 As Edeso Natalías [2009: 158] points out, "existen otra serie de eufemismos que no se atienen a esta definición. 0, mejor dicho, que nos obligan a ampliarla, ya que no sólo atenúan los posibles rasgos negativos de su referente sino que, además, acentúan o enfatizan sus rasgos positivos" [there is another group of euphemisms which do not belong to this definition. In fact they force us to widen it, as they not only attenuate possible negative features of their point of reference, but they also accentuate and emphasise its positive points].
} 
effects that euphemistic/dysphemistic uses can cause in the interlocutors, the intentional creation of all kinds of verbal and non-verbal expressions or speech acts, that, in a certain "context" or specific pragmatic situation, cover, attenuate or enhance expressively, or, on the contrary, motivate or reinforce evocatively a determined forbidden concept or reality] [Casas Gómez 2011: in press].

\section{Some expressive base mechanisms of euphemism and dysphemism}

There are many expressive base mechanisms, belonging to different linguistic planes, which can be used by these phenomena in order to modulate, substitute, alter or modify a certain forbidden concept or reality.

In this paper, we will concentrate on linguistic description with examples of two specific resources which have not been widely studied because of their singularity, but which are especially significant due to the expressiveness involved, which permits the appearance of lexical creations, such as expressive designations and blending, on some occasions through a lexical substitution and on others with a modification of form using the phonetic alteration of a forbidden content (in this case, especially the conceptual area of the prostitute).

The substitution of one taboo concept for another with an affective semantic aspect is quite common in superstitious practices and, in general, in the magical-religious sphere ${ }^{23}$. These appellatives, although they appear in some designations of "diablo" (devil), such as compadre (friend, mate), are more often found in names of animals which are tabooed for reasons of tradition or folklore. Remember, for example, the affectionate names used all over Romania an animal as apparently harmless as the weasel, or the many examples referring to the snake, the wolf and the fox in Galicia [Alonso Montero 1977: 47-58]. An uneducated person feels the need to find an inoffensive and flattering substitute in order to flee from pronouncing the animal's real name, which, in relation to the world of the supernatural, can mean, to his rural way of thinking, an imminent danger. Given that this is characteristic of primitive cultures, it is very possible that epithets like guapilla or guapiña (pretty little one), used to describe the "weasel", were grouped syntagmatically with the real name, until they later became independent, taking on its semantic value.

The affective formations related to the word prostitute are completely different, such as chipichusca [chusca = loose] (expressively accentuating the second element), piculina (possibly an italian word), pilili, pilingui, putiplista, putiflística, or titi (probably a hypercoristic use of tía $a^{\text {T.N. }}$, all of which are conditioned by three constants: 1) they are lexical creations from popular language or slang; 2) they are used mainly by women, 3) they involve a complete change in the expression -what Cela [1975:170] called ñonismo, based on the initial phoneme or phonemes. With eloquent interference, these expressive designations connect with the euphemistic phonetic distortions of the word puta that have lost their original sense, normally used as simple exclamations. In this respect, Kany [1960:170] points out that the vulgar expression hijo de puta "may be replaced by almost any word containing one or more sounds of the original that suffice to suggest its meaning", citing Hispano-American examples like país, palabra, p'arriba, perra, pinta,

23 Silva Correia [1927: 484] already included these "denominações afectuosas" [affectionate denominations] as lexical resources.

T.N. Tía means, literally, "aunt", but is also used colloquially for girl or woman. 
pita, puerca ${ }^{24}$, pulga, punta, puya, república, de la familia Putiérrez, some of which are weak paronyms basing their formal association only on the initial phoneme or syllable of the forbidden word.

The second mechanism, blending, seen as a morphological resource of composition or as a motivator of phonetic alteration presents greater possibilities for theoretical discussion. Regarding this point, I intend to follow some aspects of the guidelines established by Montero Cartelle [1981: 52 and 55], who distinguishes, on the one hand, morphologically based adjunction, using affixes which, more than changing the phonetic structure of the word, "modifican su contenido afectivo-evocativo de tal manera que la interdicción, que gravita sobre la forma primitiva, no se actualice en la derivada" [modify their affective-evocative content so that the interdiction that weighs on the primitive form has no bearing on the derivative]. These are what he calls "creadores eufemísticos por derivación" [euphemistic creators through derivation], which, obviously, are studied within the category of morphological resources. On the other hand, we have what he calls "motivadores eufemísticos por composición" [euphemistic motivators through composition], which seek the phonetic alteration of the word through procedures which connote freedom, spontaneity and imagination.

This author does not accept composition as a morphological resource, since he does not understand it in the traditional sense, seeing it from a different perspective, "como una forma más de alcanzar la alteración fonética; concretamente, la que se logra por conjunción o cruce de dos o más vocablos y por la incorporación de elementos extraños a la estructura formal de la palabra" [as another way of reaching phonetic alteration; more exactly that which is achieved by the combination and blending of two or more words and by the incorporation of new elements in the formal structure of the word] [Montero Cartelle 1981: 52]. Thus, he classifies under the single heading of composition what other scholars have considered to be two separate phenomena ${ }^{25}$. In his opinion, composition "incide casi con exclusividad sobre la estructura externa de la palabra, mientras que los recursos morfológicos lo hacen sobre su contenido sémico; bien entendido que unos y otros repercuten, en último término, en el significado de la palabra, pero, mientras los primeros lo hacen de manera indirecta (por acomodación del término marcado al no marcado), los segundos lo consiguen por adición o supresión de algún rasgo semántico" [has to do only with external word structure, whereas morphological resources have to do with the semic content. It is taken for granted that both influence the meaning of the word, but, whereas the former do so indirectly (adapting the marked term to the unmarked one), the latter do it through the addition or deletion of some semantic aspect] [Montero Cartelle 1981: 55]. His argument is quite convincing; in fact, in my own case, where I indeed mentioned some cases of creation through composition in the traditional sense of the word [Casas Gómez 1986: 142-143] such as

\footnotetext{
24 The following example, in which after the first syllable, the author makes a euphemistic or dysphemistic detour towards a word with a similar sound to the forbidden one, makes clear that the word puerca [sow] functions not only as a dysphemistic animal metaphor for "puta" but can also be used as a paronymic substitute for that word:

“-¡Habráse visto -exclamaba- mayor descoco!

¡Vaya...las mantesonas, las pu...'ercas'!” [Have you ever seen, he exclaimed, such impudence! Look at the brazen hussies, the... sows!] (Juan Valera, Juanita la Larga, Madrid, Salvat RTV, 1970: 63].

25 Silva Correia (1927: 494 and 497] separates encorpamento [enhancement, enlargement] ("para disfarçar o termo ominoso enriquece-se êste por vezes com fonemas que não lhe pertencem" [to disguise the unpleasant term it is sometimes enriched with phonemes that do not belong to it]) from cruzamentos vocabulares [blends], which may have, in certain cases, euphemistic value, as in the case of dechemo (mentioned by Gil Vicente), a combination of decho + demo, both synonyms of "devil".
} 
zorrotonadillera [fox-singer], putobailarina [whore-dancer] or putañona ${ }^{26}$ [old whore], I was obliged to decide whether to include this mechanism in the category of morphological resources or lexical ones, finally deciding to follow the linguistic tradition, given its correlation with derivation, and classify it as a morphological resource, since it is a mechanism acting on the formal plane of the forbidden word and not on the framework of its semantic relations. However, I fully agree with Montero Cartelle that, unlike morphological composition, word blending is not a morphological resource, but a phonetic one, as its basic aim is to alter the phonetic structure of the word using extraneous elements born of the speaker's own imagination.

The addition of this type of elements to the formal structure of the word is not very productive in the area of interdiction. We can mention only the case of the Extremaduran dialect word ramajera "woman with rather "free" habits" [Murga Bohigas 1979: 79], in which the adjunction of certain phonemes to the word ramera has displaced its designative value towards a related lexical sphere. It is a very important example, as it shows that this mechanism serves, not only for the euphemistic attenuation of a forbidden word, but also, as we have seen, for its associative displacement. On the other hand, the blending of two words can give rise to determinants that are not only euphemistic but also dysphemistic or humorous. In this respect, Rabanales [1958: 48] emphasised the wit used in creating a blended compound, alluding to the interpretations of the names of some personalities on the national political scene (Orejorio = oreja [ear] + Gregorio), some surnames like Dondini, which is substituted by Tontini (blended with tonto [fool]) or compounds like veterruga = veterano + arruga [wrinkle]. The lexical creations of Coll [1975: 170] follow a similar pattern, such as putetisa, a blend of puta and poetisa: "ramera aficionada a hacer versos" [a whore keen on writing verse]. In his Dictionary we can find a wide variety of examples of this type of composition and phonetic alteration by modification, adjunction or agglutination, such as those compounds, apart from the above-mentioned, relative to the lexical field of prostitution, and, in particular, to the concept of "puta": buta, cataputa, cazorra, deputación, désputa, escoputa, exputa, guardaputas, hepútico, hipopútamo, hosputal, imputencia, limpiaputas, meretrid, narizorra, neputismo, palputar, pendonar, perputar, prostitata, putamorfosis, putano, putatús, putefacta, putente, putíbulo, putilado, putinar, putocracia, putrimonio, remera, or reputiar 27.

\footnotetext{
26 The first two, using the ending in $-o$ [masculine] in the first element in analogy with other compound forms, are similar lexical creations which soften, to a certain extent, the crudity of the words zorra and puta, at the same time as they are motivated towards the concept of "tanguista-prostitute" [tango dancerprostitute]. The case of putañona is quite the contrary; the adjectival form not only suggests the meaning of the compound, but it also increases the pejorative and dysphemistic value of the base term. Furthermore, this term has two possible explanations: it could be an augmentative form of putaña or a compound, as Alcalá Venceslada suggests [1980: 513], of puta + añona ${ }^{\text {T.N. }}$, which gives rise to the acception of "old harlot".

T.N. añona would be derived from año [year].

27 Among the devotees of these lexical creations are Camilo José Cela: "-No, no crea; estas artistas no convienen; estas artistas, las que más, las que menos, suelen tener "furor puterino", suelen ser todas unos "pendones"'. [No, don't believe it; these artists aren't suitable; these artists, some more and some less, usually have "whoritis", they are usually all sluts] (El Molino de Viento, 706, cit. by Suárez Solís [1969: 438] and Álvaro de Laiglesia, in whose book Fulanita y sus Menganos (Barcelona, Planeta, 1965: 18 and 146] we find the forms deputante: "...he podido reconstruir con exactitud mis ya algo lejanos tiempos de "debutante". O dicho sea con más claridad, por si alguien no entiende el gabacho, de "deputante". Así sabrá todo el mundo lo que quiero decir" [...I have been able to reconstruct with precisión my far-off times as a "debutante". Or to put it clearly in case somebody doesn't understand frog, as a "deputante". So everyone will know what I mean] and putocracia: " $\mathrm{Q}$ ué colorados se hubieran puesto si llegan a saber que no éramos damas de la aristocracia, sino fulanas de la "putocracia"! [How they would have blushed if they'd known that we weren't aristocratic ladies,
} 
In spite of all this, word blending has been analyzed by few authors writing on the subject of interdiction, such as Mansur Guérios [1956: 25], who states that "o vocábulo tabu é substituído por um resultado do cruzamento entre aquêle e outro vocábulo" [the taboo word is substituted by the result of blending that word with another one], although he points out that it may occur that both components are taboo, as in the case of the Russian form ancipar, a euphemistic blend of "An (tikhrist) - (Lu) cipar (= Lúcifer)", or Grimes [1978: 30-31], who, although he does not mention this mechanism in the theoretical part of his work on the erotic language of the Mexicans, when he systematises the designations of the "male member", he devotes a section to humorous dysphemisms using word blending, with examples like la chúperson and la mámerson: "disfemismos humorísticos que imitan la terminación de ciertos apellidos ingleses ("Anderson", "Johnson"), o que tal vez se inspiran en los nombres de ciertas marcas de armas ("Remington", "Smith and Wesson"). Las raíces hispanas ("chupar", "mamar") simultáneamente expresan el concepto tabú por medio de una referencia al fellatio" [humorous dysphemisms which imitate the ending of some English surnames [Anderson, Johnson] or are perhaps inspired by makes of firearms (Remington, Smith and Wesson). The Spanish roots ("chupar", "mamar") express the taboo concept simultaneously by means of a reference to fellation].

The humorous dysphemistic aspect of this resource is also present in the slang term camaruta, a cross between camarera + puta which increases the motivation of the word and the real designation: "bar hostess". On the other hand, its euphemistic capacity, with vague humorous overtones is shown in another term, meregilda, found in Salvadoran popular language and gypsy dialect, with a meaning equivalent to "meretriz" (meretrix), and which is, according to Schneider [1962: 271], a "cruce de menegilda (<Hermenegilda) 'criada de servicio doméstico' y meretriz" [a cross between menegilda (from Hermenegilda -a domestic servant) and meretrix].

\section{Conclusions}

In this paper, as well as tracing an evolution of the theoretical characterisation of euphemism and dysphemism from their treatment as lexical substitutes in the Romanist tradition to their current dimension as cognitive processes of conceptualization of a certain forbidden reality, I have demonstrated, above all, the relevance acquired by creative expressiveness, exemplified in the text by some specific resources such as expressive designations and word blending, in euphemistic and dysphemistic fields. This fact dates back to the very affective ambivalence of the origin of the taboo.

The level of the connotative values expressed symptomatically by euphemistic and dysphemistic uses is such that, not only is a forbidden base term sometimes lacking, but it also explains that the boundaries between taboo and dysphemism are blurred and it even partially justifies the lack of a clear delimitation between euphemism and dysphemism, since there are all kinds of affective combinations, given the existence of numerous cases of euphemistic dysphemisms and dysphemistic euphemisms.

but tarts from the "putocracy”. Similar deformations can be found in jokes: “Qué es una pauta? / Una mujer maula" T.N. and “¿Cuál es el colmo del químico? / Tener un hijo cabronato y una hija putásica”. [What’s the definition of a chemist? Having a cuckold [cabronato, a pun on carbonato] son and a sluttish [putásica, a pun on potásica] daughter].

T.N. A pun on the vowel sounds: puta/pauta and mala/maula. Pauta means guideline, maula does not exist. 
Finally, there has been great insistence on the fact that this expressive capacity of euphemism and dysphemism is manifested, above all, in its communicative function, not so much for covering or for attenuation or politeness, but more for enhancement, that accompanies certain euphemistic creations for "puffery", shown in the social advancement and greater prestige of jobs, trades and professions, and carefully formulated in the domain of political correct language. This circumstance has led to a change in our definition of euphemism and dysphemism with the incorporation of new aspects of the linguistic description of these phenomena.

\section{Bibliography}

AlCalá Venceslada Antonio, Vocabulario andaluz, Madrid: Gredos, 1980.

AlCARAZ Varó Enrique and Martínez Linares María Antonia, Diccionario de lingüística moderna, Barcelona: Ariel, 1997.

Allan Keith and BurRIDGE Kate, Euphemism and Dysphemism. Language Used as Shield and Weapon, New York, Oxford: Oxford University Press, 1991.

Allan Keith and BuRRIDGE Kate, Forbidden Words. Taboo and the Censoring of Language, Cambridge, New York: Cambridge University Press, 2006.

Alonso Montero Xesús, "Denominaciones gallegas de la culebra, el zorro y el lobo. (Una incursión en la lingüística del tabú y de la expresividad)", Lingua, literatura $e$ sociedade en Galicia, Madrid: Akal, 1977: 45-47.

Armenta Moreno Luisa María, La interdicción lingüística: estrategias del lenguaje políticamente correcto en textos legales educativos. Selección de leyes educativas (19862006), Tesis doctoral, Cáceres: Universidad de Extremadura, 2009a.

ARMenta Moreno Luisa María, "La interdicción lingüística en textos legales educativos (1986-2006)”, Pragmalingüística, Vol. 17, 2009b: 8-27.

Armenta Moreno Luisa María, "Usos eufemísticos y disfemísticos en las denominaciones de la profesión docente", Sintagma, Vol. 22, 2010: 115-129.

BenVEniste Émile, "La blasfemia y la eufemia", Problemas de lingüística general, Vol. II, Madrid: Siglo XXI, 1977: 256-260.

BuEno Silveira, "Tabus, eufemismos e disfemismos", Tratado de Semântica Brasileira, São Paulo: Ed. Saraiva, 1960, 3a ed.: 199-246.

Carnoy Albert, La science du mot. Traité de Sémantique, Louvain : Éditions 'Universitas', 1927.

CASAS Gómez Miguel, La interdicción lingüística. Mecanismos del eufemismo y disfemismo, Cádiz: Universidad de Cádiz, 1986.

CASAS GómEz Miguel, “A propósito del concepto lingüístico de eufemismo como sincretismo léxico: su relación con la sinonimia y la homonimia”, Iberoromania, Vol. 37, 1993: 7090.

CASaS Gómez Miguel, Contribución al estudio del léxico eufemístico/disfemístico. Las designaciones de la "prostituta" en el español moderno, Barcelona: ETD Micropublicaciones, S.L., 1994.

CaSas Gómez Miguel, “Sinonimia y eufemismo”, Quaderni di Semantica, Vol. 16,1, 1995: 1746.

CASAS Gómez Miguel, "El poder mágico de la palabra", Trivium. Anuario de Estudios Humanísticos, 8. In memoriam Prof. José Luis Millán Chivite, 1996: 29-52. 
CASAS Gómez Miguel, “Tabú de palabra e interdicción conceptual”, PAMIES BERTRÁN Antonio, LUQUE DURÁN Juan de Dios (Eds.), Trabajos de lexicografía y fraseología contrastivas, Granada: Método Ediciones, 2000: 79-98.

CASAS GómEz Miguel, "Precisiones conceptuales en el ámbito de la interdicción lingüística”, SAntos Río Luis, BorRego Nieto Julio, García SAntos Juan Felipe, Gómez AsEnCio José J., PRIETO DE LOS Mozos Emilio (Eds.), Palabras, norma, discurso. En memoria de Fernando Lázaro Carreter, Salamanca: Ediciones Universidad de Salamanca, 2005: 271-290.

CASAS GómEz Miguel, "Towards a new approach to the linguistic definition of euphemism", Language Sciences, Vol. 31, 2009: 725-739.

CASAS Gómez Miguel, "De una visión léxica y pragmático-discursiva a una dimensión cognitiva en la caracterización extralingüística y lingüística del eufemismo", HoRAK André, ToRre, Mariela de la (Eds.), Estudios pragmático-discursivos sobre el eufemismo. Actes du Colloque International L'euphémisme revisité. Nouvelles perspectives pragmatico-discursives (Université de Berne, 2 et 3 septembre 2010), Frankfurt am Main : Peter Lang, Studien zur romanischen Sprachwissenschaft und interkulturellen Kommunikation, 2011: en prensa.

CEla Camilo José, Diccionario secreto, 3 vols., Madrid, Barcelona, Alfaguara, 1975.

CEla Camilo José, Enciclopedia del erotismo, 4 vols., Madrid: Sedmay Ediciones, 1976-77.

CERDÀ Ramón (Coord.), Diccionario de lingüística, Madrid: Anaya, 1986.

Chamizo Domínguez Pedro J., "La función social y cognitiva del eufemismo y del disfemismo", Panace@, Vol. V/15, 2004: 45-51.

Chamizo Domínguez Pedro J., "Some theses on euphemisms and dysphemisms", Studia Anglica Resoviensia, Vol. 3, 2005: 9-16.

Chamizo Domínguez Pedro J., "Tabú y lenguaje: las palabras vitandas y la censura lingüística”, Thémata. Revista de Filosofía, Vol. 40, 2008: 31-46.

Chamizo Domínguez Pedro J., "Linguistic interdiction: Its status quaestionis and possible future research lines", Language Sciences, Vol. 31.4, 2009: 428-446.

Chamizo Domínguez Pedro J. and Sánchez Benedito Francisco, "Euphemism and Dysphemism: Ambiguity and supposition", Language and Discourse, Vol. 2, 1994: 7892.

Chamizo Domínguez Pedro J. and SánChez Benedito Francisco, Lo que nunca se aprendió en clase. Eufemismos y disfemismos en el lenguaje erótico inglés, Granada, Comares, 2000.

Coll José Luis, El diccionario de Coll, Madrid: Planeta, 1975.

Contreras Lidia, "Semántica del español americano. (Notas al libro de Kany)", Revista Portuguesa de Filología, Vol. 14, 1966-68: 157-195.

CRESPo FERNÁndez Eliecer, "Euphemistic strategies in politeness and face concerns", Pragmalingüística, Vol. 13, 2005: 77-86.

CResPo Fernández Eliecer, El eufemismo y el disfemismo. Procesos de manipulación del tabú en el lenguaje literario inglés, Alicante: Universidad de Alicante, 2007.

Crespo Fernández Eliecer, "Sex-Related Euphemism and Dysphemism: An Analysis in Terms of Conceptual Metaphor Theory", ATLANTIS. Journal of the Spanish Association of Anglo-American Studies, Vol. 30.2, 2008: 95-110.

DANIEL Pilar, "Panorámica del argot español", LEÓN, Víctor, Diccionario de argot español y lenguaje popular, Madrid: Alianza, 1980: 7-27.

EDESo Natalías Verónica, "Revisión del concepto de eufemismo: una propuesta de clasificación", Revista Internacional de Lingüística Iberoamericana, Vol. VII.2(14), 2009: 147-163.

Freud Sigmund, Tótem y Tabú, Madrid: Alianza, 1967. 
Galli DE' PaRATESI Nora, Le brutte parole. Semantica dell'eufemismo, Torino: Arnoldo Mondadori Editore, 1973, 3a ed.

GómEz SÁNCHEz María Elena, El eufemismo político y económico en la prensa diaria: Análisis de ABC y El País (1998), Tesis doctoral inédita, Madrid: Facultad de Ciencias de la Información, Universidad Complutense de Madrid, 2004.

Grimes Larry M., El tabú lingüístico en México: el lenguaje erótico de los mexicanos, New York: Ed. Bilingual Press, 1978.

GUITART ESCUDERO María Pilar, Lenguaje político y lenguaje políticamente correcto en España (con especial atención al discurso parlamentario), Tesis doctoral, Valencia: Universidad de Valencia, 2003.

GuitaRT EsCUDERo María Pilar, Discurso parlamentario y lenguaje políticamente correcto, Madrid: Congreso de los Diputados, 2005.

Hernández Flores Nieves, "La cortesía como la búsqueda del equilibrio de la imagen social”, Bravo Diana, BRIZ GómEz Antonio (Eds.), Pragmática sociocultural: estudios sobre el discurso de cortesía en español, Barcelona: Ariel, 2004: 95-108.

HoRAK André, L'Euphémisme. Entre tradition rhétorique et perspectives nouvelles, München : LINCOM, 2010.

Kany Charles E., American-Spanish Euphemisms, Berkeley-Los Angeles: University of California Press, 1960.

KANY Charles E., Semántica hispanoamericana, Madrid: Aguilar, 1969.

KRöLl Heinz, "Algunos eufemismos en el portugués coloquial y popular", Cuadernos de Filología. Studia Linguistica Hispanica, Vol. II,2, 1981: 105-119.

KröLl Heinz, O eufemismo e o disfemismo no português moderno, Lisboa: Instituto de Cultura e Língua Portuguesa, 1984.

LECHADO GARCía José Manuel, Diccionario de eufemismos y de expresiones eufemísticas del español actual, Madrid: Verbum, 2000.

LEón Víctor, Diccionario de argot español y lenguaje popular, Madrid, Alianza, 1980.

LEWANDOWSKI Theodor, Diccionario de lingüística, Madrid: Cátedra, 1982.

LóPEz EIRE Antonio, "Sobre el eufemismo en la Oratoria ática y en la Retórica", MARTINo Francesco de, Sommerstein Alan H. (Eds.), Studi sull'eufemismo, Bari: Levante, 1999: 313-367.

LuQue Durán Juan de Dios, PAMIES BERTRÁn Antonio, MANJón PoZAS Francisco José, El arte del insulto. Estudio lexicográfico, Barcelona: Ediciones Península, 1997.

MANSUR GuÉRIos Rosário Farâni, Tabus lingüísticos, Rio de Janeiro: Organização Simões Editora, 1956.

MARTín Jaime, Diccionario de expresiones malsonantes del español, Madrid: Istmo, 1979, 2ª ed.

Montero CarTelle Emilio, El eufemismo en Galicia (su comparación con otras áreas romances), Santiago de Compostela: Universidad de Santiago de Compostela, 1981.

MonteroCartelle Enrique, Aspectos léxicos y literarios del latín erótico (hasta el s. I. d. C.), Santiago de Compostela: Universidad de Santiago de Compostela, 1973.

Murga Bohigas Antonio, Habla popular de Extremadura. Vocabulario, Madrid: Gráficas Alvi, 1979.

NyRoP Kristoffer, Grammaire historique de la langue française, IV: La sémantique, Copenhague : Gyldendalske Boghandel Nordisk Forlag, 1913.

RABANALES Ambrosio, "Recursos lingüísticos, en el español de Chile, de expresión de la afectividad", Boletín de Filología. Universidad de Chile, Vol. 9, 1958: 205-302. 
RADTKE Edgar, Typologie des sexuell-erotischen Vocabulars des heutigen Italienisch: Studien zur Bestimmung der Wortfelder "prostituta" und "membro virile" unter besonderer Berücksichtigung der übrigen romanischen Sprachen, Tübingen: Narr, 1980.

RESTREPo Félix, Diseño de semántica general. El alma de las palabras, Barcelona: Imp. Editorial Barcelonesa, 1917.

REUTNER Ursula, "El eufemismo como fenómeno cultural y lexicográfico", Lingüística Española Actual, 2010: en prensa.

RodChenko Anna, Algunos aspectos de la variabilidad de los eufemismos en el español contemporáneo, Documento de internet: http://hispanismo.cervantes.es/documentos/rodchenko.pdf

Rodríguez AdRados Francisco, "Estructura del vocabulario y estructura de la lengua", Problemas y principios del estructuralismo lingüístico, Madrid, CSIC, 1967: 193-229.

SCHNEIDER Hans, "Notas sobre el lenguaje popular y caló salvadoreños", Romanistisches Jahrbuch, Vol. XIII, 1962: 252-272.

SENABRE Ricardo, "El eufemismo como fenómeno lingüístico", Boletín de la Real Academia Española, Vol. 51, 1971: 175-189.

Silva CoRreia João da, "O eufemismo e o disfemismo na língua e na literatura portuguesa”, Arquivo da Universidade de Lisboa, Vol. 12, 1927: 445-787.

SuÁrez Solís Sara, El léxico de Camilo José Cela, Madrid-Barcelona: Alfaguara, 1969.

UllmanN Stephen, Semántica. Introducción a la ciencia del significado, Madrid: Aguilar, 1976.

URía VARELA Javier, Tabú y eufemismo en latín, Amsterdam, A. M. Hakkert-Publisher, 1997. VENDRYES Joseph, El lenguaje. Introducción lingüística a la historia, México: UTEHA, 1967.

WARREN Beatrice, "What Euphemisms Tell us about the Interpretation of Words", Studia Linguistica, Vol. 46.2, 1992: 128-172.

WidŁaK Stanislaw, "Le fonctionnement de l'euphémisme et la théorie du champ linguistique: domaine roman", Actas del XI Congreso Internacional de Lingüística y Filología Románicas, Madrid, 1965, Vol. 2, Madrid: 1968: 1031-1052.

WidŁaK Stanislaw, Moyens euphémistiques en italian contemporain, Kraków: Nakładem Uniwersytetu Jagiellońskiego, 1970.

WidŁAK Stanislaw, Alcuni aspetti strutturali del funzionamento dell'eufemismo. Antonimia, sinonimia, omonimia e polisemia, Wrocław, Warszawa, Kraków, Gdańsk: Accademia Polacca delle Scienze, 1972. 